\title{
Seed crystal
}

The perils of research.

Our Alamogordo was the biocontainment laboratory on Wreckyn Street, and our Trinity Test was a squirt of gas in the face of a docile pig that someone had wittily named Hamdora. We used a pig - a Göttingen mini-pig, it was called in the buyer's guide because its organs were sufficiently similar to those of humans; and humans were, after all, what everyone was interested in. What I remember most clearly are the sounds: a loud crunch heralding the first reactions between the microscopic seed-crystals and the animal's skin, and then a series of dainty cracks, like cellophane, as its carbon atoms snapped into configuration with the new, low-energy allotrope. Somewhere during that process, before it turned into stone and then flaked into ash, the pig screamed like a child. I had just calculated in my head that the reaction rate was within $10 \%$ of my model, and to me, at the time, it sounded like a shriek of triumph.

I'd only ever been interested in carbon allotropes for their material properties - I had thought I was going to invent the perfect nanobotlubricant-butthat night I celebrated as hard as the others. We'd all gone to some club in the city that somebody knew, and soon I'd had one too many Guinness-andGod-knows-whats and a technician I'd never seen without a lab coat before was screaming at me above the music that the best thing about this new chemical weapon (it wasn't exactly a chemical reaction, I shouted unheard) was that it could kill the enemy yet leave their city undamaged. "It was so sad when that museum in Baghdad got looted," she yelled. "I love art so much."

I walked out of the club and thought about the perfection of the weapon. Cheap, instantaneous and, after death, selfneutralizing. As potent as an atomic bomb but able to be carried by a single person. I breathed the fresh night air and surveyed the cityscape twinkling optimistically far below. Then I threw myself off the cliff.
Naturally, after that I had my security clearance rescinded, so when I left the hospital I was a scientific free agent once more. Who was I to look up to? Was I to be like Sakharov, winning recognition for fighting the evils of my own invention? The hypocrisy sickened me. I decided to wash my hands of good and evil entirely. From here on in, I vowed, my science would be for the use of irrelevance only.

I began in my garden. I took a bioskeletal frame developed for shaping artificial body parts in the lab, and used it to grow synthetic vegetables in novelty shapes. My 'Hello Kitty' strawberries briefly had the fastest-growing shares in the world. I reapplied my technique to flesh and marketed Victimless Steaks to classy restaurants and, eventually, McDonalds. Angelina Jolie became our spokesperson, and farmers burnt her in effigy at protest rallies that were, increasingly, stormed by PETA.

I ignored the politics and concentrated on irrelevant science. I was interested in how rubbing a tomato stake in a certain way made the earthworms emerge like spaghetti from the topsoil. I discovered their favourite frequency and won the Eighth International Worm Grunting Festival in Sopchoppy, Florida. I had a paper published. I saw it mentioned in the back of a popular science magazine.

Like many scientists I became annoyed by the need to interrupt my work with sleep. I studied slow-wave EEG asymmetries in dolphins and migrating birds and discovered where to sever my brain to allow the hemispheres to rest alternately. My productivity doubled. I toyed with neurological explanations of phantom limb syndrome and sold my findings to Nintendo, who brought out a Wii console with a proprioceptive controller. I spliced glow-in-the-dark jellyfish genes into grass and created intoxicating lawnscapes for millionaires. Nightclubbers, I discovered, were my largest market for phosphorescent hair.

It wasn't long before the Vatican decreed that my cubic, stackable, headless, limbless and irresistibly tasty Brick-a-Chickens ${ }^{\mathrm{Th}}$ were an affront to God, and fanatics in the Holy Office summoned Catholics to a religious war against genetic scientists. Four Nobel laureates were killed by car bombs in the space of three months. In a rushed and secret deal, Monsanto bought the whole artificial animal and vegetable business and started exporting. Within a year, the nutrition of 32 developing nations was as dependent on Western corporations as newborn babes. Three hundred million died in the stock market dip of last March.

Someone in the army read my wormcharming paper. They developed a buzzing grenade to flood enemy territory with creepy-crawlies, which field tests showed to be psychologically devastating. Armies now douse occupied land with toxic chemicals as a routine precaution, and it is estimated that it will be decades before plants can grow again in significant portions of Africa and Asia Minor.

In contrast, my glowing lawns ran amok in large parts of Europe and aggressively displaced all other grass species. In confusion, nocturnal animals stopped feeding; owls are now endangered and human disease is increasing in proportion to the rats.

A leaked Pentagon document reveals that sleepless infantrymen can now each control up to eight proprioceptive weaponscarrying robot arms. Rapid military victories were had before the ranks were gutted by depression and suicide. In Japan, thousands of salarymen committed hara-kiri instead of submitting to company pressure for the antisleep procedure; on university campuses, however, it is routine.

I am now a wiser human being. I have learned that even worm-charming contains the key to the gates of Hell. That is why I am again standing on this cliff, and why this time my pocket is reassuringly fat with a fragile gas-filled bottle, smuggled from my old digs on Wreckyn Street.

\section{Tania Ritchie}

Tania Ritchie lives in Newcastle, Australia, and is studying for her PhD in chemical engineering. 